\title{
Market Efficiency For S\&P 500: 1954-2004
}

\author{
Massoud Metghalchi, (Email: MetghalchiM@uhv.edu), University of Houston-Victoria \\ Xavier Garza-Gómez, University of Houston-Victoria \\ Chien-Ping Chen, University of Houston-Victoria \\ Stanley Monsef, Southern Nevada Community College
}

\begin{abstract}
This paper tests three moving average technical trading rules for the $S \& P 500$ stock index. Using daily data from 1954 to 2004, our results indicate that moving average rules did indeed had predictive power and could discern recurring-price patterns for the period up to mid 1980s. However, since mid 1980s, technical trading rules do not work and could not discern recurringprice patterns. Our results are consistent with market inefficiency from 1954 to 1984 and market efficiency from 1984 to present.
\end{abstract}

\section{INTRODUCTION}

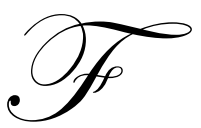

ama (1970) defined an efficient financial market as one in which security prices always fully reflect the available information; any new information will be quickly and instantaneously reflected in prices. Furthermore, since news on any company, by definition, is unpredictable (arrives randomly), price changes will be unpredictable or follow a random walk. Fama made a distinction between three forms of Efficient Market Hypothesis (EMH): (a) the weak form, (b) the semi-strong form, and (c) the strong form. Advocates of the weak-form market efficiency hypothesized that investors could not drive profits above a buy-and-hold strategy using any trading rule that depended solely on past market information such as price or volume, implying that technical trading rules are useless.

After more than three decades of research and literally thousands of journal articles, financial economists and practitioners have not yet reached a consensus whether technical trading rules could discern recurring-price patterns for profitable trading. The overwhelming majority of financial economists support the "weak-form" efficient market hypothesis. This is because much of earlier research supported the random walk hypothesis. While the semi-strong form of EMH has formed the basis for most empirical research, the following studies have long supported the weakform market efficiency: Larson (1960), Osborne (1962), Alexander (1964), Granger and Morgenstern (1963), Mandelbrot (1963), Fama (1965), Fama and Blume (1966), Van Horn and Parker (1967), Jensen and Benington (1970).

However since early the1990s, technical trading has been enjoying a renaissance both on Wall Street and in academic circles. Several papers have presented evidence that some simple trading rules are useful for predicting stock market returns. The cornerstone of this new research on technical analysis is an article by Brock, Lakonishok and LeBaron, (BLL 1992), BLL analyzed moving averages and trading range breaks on the Dow Jones Industrial Index from 1897 to 1985 . They used various short and long moving averages of prices to generate buy and sell signals. They tested long moving averages of 50,150 and 200 days with short averages of 1,2 and 5 days. They point out that "all buy-sell differences are positive and the t-tests for these differences are highly significant..." and they go on to conclude that their "results are consistent with technical rules having predictive power". Other researchers have used some variants of BLL's moving averages to investigate whether stock market indices can be predicted by some simple form of technical analysis. Bessembinder and Chan (1995) conclude that the BLL's rules are successful in predicting stock price movement in Japan, Hong Kong, South Korea, Malaysia, Thailand and Taiwan, with the predictability strongest in the last three markets. Ergul, Holmes and Priestley (1997), using daily closing prices of 63 stocks traded on the Istanbul Stock Exchange, conclude that technical analysis on volume can aid the prediction of returns which cannot be predicted by the analysis of past returns in isolation. Pruitt and White (1998), using the University of Chicago's CRSP daily data tapes over the 1976-1985 period, conclude that technical trading rules are 
capable of outperforming a simple buy-and-hold strategy even adjusting for transaction costs. Bessembinder and Chan (1998) confirm the basic BLL results; however, they argue that the BLL results can coexist with the notion of market efficiency when considering transaction costs. Gencay (1998a, 1998b), Ratner and Leal (1999) also support the predictive power of technical trading rules. Kwon and Kish (2002), applying three popular technical trading rules to NYSE index over the period 1962-1996, conclude that the technical trading rules have the potential to capture profit opportunities over various models when compared to buy and hold strategy. However, in a recent study, Ready (2002) points out that the apparent success of the BLL moving average rules is a spurious result of data snooping and need not persist in the future. Technical trading rules have also been applied to foreign exchange markets. For a survey of technical trading on foreign exchange markets, see Taylor and Allen (1992) and Maillet and Michel (2000). In this paper, we use 5 decades of data to investigate whether changes in the S\&P 500 index can be predicted by some form of technical analysis.

\section{DATA AND METHODOLOGY}

We use Global Finance's daily closing price index of the S\&P 500 from 1954 to 2002 and DataStream's daily closing price index for 2003 to February 24, 2004 and compute daily returns as changes in logarithms of the stock index level. We estimate approximate annualized returns on the basis of 260 trading days per year as exponential (260R) -1 , where $\mathrm{R}$ is the average daily return.

Technical analysis is based on the idea that prices move in trends which are determined by the changing attitudes of traders towards various economics, political and psychological forces. As Pring (1991) points out "the art of technical analysis is to identify trend changes at an early stage and to maintain an investment posture until the weight of evidence indicates that the trend has reversed". One of the most important Trend-Determining Techniques is based on the crossing of two moving average (MA) of prices. According to this rule, buy (sell) signals are emitted when the short short-term moving average exceeds (is less than) the long-term average by a specified percentage. In this study we use long moving averages of 50,100,150 and 200. As for the short moving average, like the BLL study, we use 1 day (the raw return) moving average. (We have also used 5 and 10 days short MA; the results were not significantly different from 1-day MA). Thus, a buy signal is emitted when the short moving average breaks the long one from below and a sell signal is emitted when the short moving average breaks the long from above.

We define $\mathrm{P}_{\mathrm{t}}$ as the short moving average or the raw index level at time $t$, and define long moving average of $\mathrm{M}$ at time $\mathrm{t}$ as:

$\mathrm{MA}_{\mathrm{t}}(\mathrm{M})=\frac{1}{M} \sum_{i=0}^{M-1} P_{t-i}$

We will test three moving average rules; the standard moving average rule (SMA), the increasing moving average rule (IMA), and the Arnold and Rahfeldt (1986) moving average rule, (ARMA). As for trading the index, we will be either in the market (buy days) or out of the market (sell days). We assume that a trader following these MA strategies could presumably observe the prices a few minutes prior to the day's close and make the trading decision at the close. If the closing price is above the long moving average, then the trader will be in the market next day by buying the index at the closing price (next day will be a buy day). Next day's return will be the difference between the logarithm of the closing price next day and the logarithm of closing price the previous day. On the other hand, if the closing price is below the long moving average, then we will sell the index at the closing price and will be out of the market next day (sell days). For the increasing MA rule, the buy days are the same as standard MA rule plus the requirement that the long run MA should be increasing (positive slope). The ARMA trading rules compare the price level with two moving averages: moving average short and long. If the price index is above both moving average short and moving average long, the rule emits a buy signal and we will be in the market (buy days); we will be out of the market (sell days) if the price is below either moving average. We define mean buy and mean sell returns as follows: 
$\mathrm{X}(\mathrm{b})=\frac{1}{N_{(b)}} \sum R_{b}$

$\mathrm{X}(\mathrm{s})=\frac{1}{N_{(s)}} \sum R_{s}$

where, $\mathrm{N}_{(\mathrm{b})}$ and $\mathrm{N}_{(\mathrm{s})}$ are total number of buy and sell days and $\mathrm{R}_{\mathrm{b}}$ and $\mathrm{R}_{\mathrm{s}}$ are daily returns of buy and sell days.

We will test whether the returns of any moving average trading rules are greater than a buy and hold strategy and whether the mean buy is different than the mean sell. More specifically:

$\mathbf{H}_{0}: \quad \mathrm{X}(\mathrm{b})-\mathrm{X}(\mathrm{h})=0, \mathrm{X}(\mathrm{s})-\mathrm{X}(\mathrm{h})=0, \mathrm{X}(\mathrm{b})-\mathrm{X}(\mathrm{s})=0$

$\mathbf{H}_{\mathrm{A}}: \quad \mathrm{X}(\mathrm{b})-\mathrm{X}(\mathrm{h}) \neq 0, \mathrm{X}(\mathrm{s})-\mathrm{X}(\mathrm{h}) \neq 0, \mathrm{X}(\mathrm{b})-\mathrm{X}(\mathrm{s}) \neq 0$

where $\mathrm{X}(\mathrm{h})$ is the mean return for the buy-and-hold strategy. The test statistic for the mean buy returns over the mean buy-and hold strategy is:

$\mathrm{t}=\frac{X(b)-X(h)}{\sqrt{\operatorname{Var}(b) / N_{b}+\operatorname{Var}(h) / N}}$

where $\operatorname{Var}(b)$ and $\operatorname{Var}(\mathrm{h})$ are the variance of buy and buy-and-hold returns respectively. The above formula is also used to test the mean sell returns over the mean buy-and-hold strategy; and the mean buy returns over the mean sell returns by replacing the appropriate variables in the t-statistic formula.

\section{EMPIRICAL RESULTS}

For the entire period the daily average of buy-and-hold strategy is 0.00030 ( 0.030 percent $)$ with a standard deviation of 0.00919 . The t-value for the buy and hold strategy for the entire period (12625 observations) is equal to $3.64(.00030$ divided by $.00919 / \sqrt{12625})$. The annual average over the entire period is $8.04 \%$. In this paper, we compare all t-statistics with 1.96 , the critical $\mathrm{t}$-value at 5 percent level for large numbers of observations. The unconditional mean for the entire period is significantly different from zero; implying positive average daily returns.

Table I summarizes the results of standard moving average trading rules. Most of these trading rules have been used in the BLL study. The rules are described as (1, long, percentage). For each rule we report mean returns on buy days and sell days, standard deviations of returns on buy and sell days, and total number of buy and sell days. The numbers in the parentheses are the t-statistics (equation 4) testing the difference of the mean buy and mean sell from the unconditional 1-day mean, and buy-sell from zero.

The first row of Table I reports results of trading rule of $(1,50,0)$; we will be in the market (buy days) if the MA1 (price level) is greater than MA50 and out of the market (sell days) if MA1 is less than or equal to MA50. For the sake of the space, we have reported the results for the short moving average of one and long moving average of $50,100,150$, and 200 for the full sample and 5 sub-periods. Using a band of $1 \%$ or $2 \%$ does not affect the results.

The buy-sell differences (column 4) for the entire period is positive and the t-stats for this difference is highly significant, rejecting the null hypothesis of equality with zero. The buy-sell differences for the two sub-periods 195463 and 1964-73 are positive and statistically significant, however, these buy-sell differences for the sub-periods 197483, 1984-93, and 1994-2004 are not significant, implying that we cannot reject the hypothesis that the mean buy days returns are equal to mean sell days returns for these three sub-periods. The mean buy and sell returns are shown in columns 2 and 3 . All of the t-values show that we cannot reject the null hypothesis that the buy returns equal the 
unconditional 1-day return. For the sells, the results are the same. All of the t-values imply that we cannot reject the null hypothesis that the sell returns equal the unconditional 1-day return. The standard deviations of buy days and sell days are reported in Columns 5 and 6 . The standard deviations for buy days are always smaller than those for sell days for the full sample. This implies that the market is less volatile for buy periods than sell periods. Columns 7 and 8 reports the number of buys and sells for various rules

\section{Table I}

\begin{tabular}{|c|c|c|c|c|c|c|c|}
\hline \multicolumn{8}{|c|}{ Statistical Results for Standard Moving Average Rules } \\
\hline \multicolumn{8}{|c|}{$\begin{array}{l}\text { Results for daily data from } 4 / 1 / 88-2 / 25 / 04 \text {. Rules are identified as (short, long, band) where short and long are the short } \\
\text { and long moving averages and band is percentage difference to generate a signal. } \mathrm{N}_{\mathrm{b}} \text { and } \mathrm{N}_{\mathrm{s}} \text { are the number of buy and } \\
\text { sell signals reported in each period. } \mathrm{SD}_{\mathrm{b}} \text { and } \mathrm{SD}_{\mathrm{s}} \text { are standard deviation of buy and sell signals, respectively. The } \\
\text { numbers in the parentheses are the t-statistics testing the difference of the mean buy and mean sell from the } \\
\text { unconditional 1-day mean, and buy-sell from zero. Numbers marked with asterisks are significant at the } 5 \% \text { level for a } \\
\text { two-tailed test. }\end{array}$} \\
\hline Rules & Buy & Sell & Buy-Sell & $\mathbf{S D}_{\mathrm{b}}$ & SD $_{\mathrm{s}}$ & $\mathbf{N}_{\mathbf{b}}$ & $\mathbf{N}_{\mathrm{s}}$ \\
\hline \multicolumn{8}{|c|}{ Full Sample: $1 / 2 / 1954-2 / 24 / 2004$} \\
\hline$(1,50,0)$ & $\begin{array}{c}0.00045 \\
(1.32) \\
\end{array}$ & $\begin{array}{c}0.00003 \\
-(1.43) \\
\end{array}$ & $\begin{array}{c}0.00042 \\
(2.25)^{*}\end{array}$ & 0.00759 & 0.01141 & 7964 & 4661 \\
\hline$(1,100,0)$ & $\begin{array}{c}0.00039 \\
(.84)\end{array}$ & $\begin{array}{c}0.00011 \\
(-.95)\end{array}$ & $\begin{array}{c}0.00028 \\
(1.44)\end{array}$ & 0.00758 & 0.01164 & 8200 & 4375 \\
\hline$(1,150,0)$ & $\begin{array}{c}0.00045 \\
(1.37)\end{array}$ & $\begin{array}{c}-0.00003 \\
(-1.59)\end{array}$ & $\begin{array}{c}0.00048 \\
(2.39)\end{array}$ & 0.00761 & 0.01173 & 8305 & 4220 \\
\hline$(1,200,0)$ & $\begin{array}{c}0.00067 \\
(1.78)\end{array}$ & $\begin{array}{c}-0.00030 \\
(-1.97)\end{array}$ & $\begin{array}{c}0.00097 \\
(2.98)\end{array}$ & 0.00951 & 0.01590 & 8465 & 4010 \\
\hline Average & $\begin{array}{c}0.00049 \\
(1.33) \\
\end{array}$ & $\begin{array}{c}-0.00005 \\
(-1.49) \\
\end{array}$ & $\begin{array}{c}0.00054 \\
(2.66)\end{array}$ & 0.00807 & 0.012672 & 8233.5 & 4316.5 \\
\hline \multicolumn{8}{|c|}{ Sub-period : $1954-1963$} \\
\hline Average & $\begin{array}{c}0.00061 \\
(1.06)\end{array}$ & $\begin{array}{c}-0.00012 \\
(-1.36)\end{array}$ & $\begin{array}{l}0.00074 \\
(1.96)^{*}\end{array}$ & 0.00614 & 0.00933 & 1666.25 & 724.75 \\
\hline \multicolumn{8}{|c|}{ Sub-period : 1964-1973 } \\
\hline Average & $\begin{array}{c}0.00035 \\
(1.35)\end{array}$ & $\begin{array}{c}-0.00028 \\
(-1.23)\end{array}$ & $\begin{array}{c}-0.00063 \\
(2.05)^{*}\end{array}$ & 0.00486 & 0.00895 & 1528.25 & 965.75 \\
\hline \multicolumn{8}{|c|}{ Sub-period : 1974-1983 } \\
\hline Average & $\begin{array}{c}0.00048 \\
(0.90)\end{array}$ & $\begin{array}{c}-0.00013 \\
(-0.97)\end{array}$ & $\begin{array}{c}0.00061 \\
(1.61)\end{array}$ & 0.00877 & 0.00990 & 1401 & 1127 \\
\hline \multicolumn{8}{|c|}{ Sub-period : 1984-1993 } \\
\hline Average & $\begin{array}{c}0.00038 \\
(-0.11)\end{array}$ & $\begin{array}{c}0.00046 \\
(0.12)\end{array}$ & $\begin{array}{c}-0.00008 \\
(-0.19)\end{array}$ & 0.00803 & 0.01543 & 1881.5 & 647.5 \\
\hline \multicolumn{8}{|c|}{ Sub-period : 1994-2/24/2004 } \\
\hline Average & $\begin{array}{c}-0.01723 \\
(0.06)\end{array}$ & $\begin{array}{c}0.01772 \\
(-0.07)\end{array}$ & $\begin{array}{c}-0.02744 \\
(0.11)\end{array}$ & 0.00695 & 0.01106 & 1756.5 & 851.5 \\
\hline
\end{tabular}

Table II summarizes the results of increasing moving average trading rules. The trading rule for IMA is as follows:

If P> MA (long) and if MA (long) is up sloping, then we are in the market (buy days).

If $\mathrm{P} \leq \mathrm{MA}$ (long) or if MA (long) is down sloping, then we are out of the market (sell days).

For each rule we report mean returns on buy days and sell days, standard deviations of returns on buy and sell days, and total number of buy and sell days. The numbers in the parentheses are the t-statistics (equation 4) testing the difference of the mean buy and mean sell from the unconditional 1-day mean, and buy-sell from zero. 
The buy-sell differences (column 4) for the entire period is positive and the t-stats for this difference is highly significant, rejecting the null hypothesis of equality with zero. The buy-sell differences for three sub-periods 1954-63, 1964-73, and 1974-83 are positive and statistically significant, rejecting the null hypothesis of equality with zero; however, these buy-sell differences for the sub-periods 1984-93, and 1994-2004 are not significant, implying that we cannot reject the hypothesis that the mean buy days returns is equal to mean sell days returns for these two subperiods. The mean buy and sell returns are shown in columns 2 and 3. The full sample t-values for mean buy and mean sell are highly significant, rejecting the null hypothesis that the buy and sell returns equal the unconditional 1day return, however, all of the t-values for mean buy or mean sell for each sub-period are low implying that we cannot reject the null hypothesis that the buy returns equal the unconditional 1-day return in each sub-period. The standard deviations of buy days and sell days are reported in Columns 5 and 6 . The standard deviations for buy days are always smaller than those for sell days for the full sample. This implies that the market is less volatile for buy periods than sell periods. Columns 7 and 8 report the number of buys and sells for various rules.

\section{Table II}

\begin{tabular}{|c|c|c|c|c|c|c|c|}
\hline & & al Results & Increasing & ving Ave & Rules & & \\
\hline $\begin{array}{l}\text { Results for } \\
\text { and long } \mathrm{n} \\
\text { sell signal } \\
\text { numbers } \\
\text { unconditio } \\
\text { two-tailed }\end{array}$ & $\begin{array}{l}\text { rom } 4 / 1 / 88 \\
\text { ges and ba } \\
\text { each per } \\
\text { theses are } \\
\text { ean, and b }\end{array}$ & $\begin{array}{l}/ 04 \text {. Rules } \\
\text { percentage } \\
\text { SDb and S } \\
\text { t-statistics } \\
11 \text { from zerc }\end{array}$ & $\begin{array}{l}\text { dentified a } \\
\text { erence to g } \\
\text { re standar } \\
\text { ing the di } \\
\text { ambers ma }\end{array}$ & $\begin{array}{l}\text { hort, long, } \\
\text { rate a sign } \\
\text { eviation o } \\
\text { ence of t } \\
\text { l with aste }\end{array}$ & $\begin{array}{l}\text { d) where } \\
\mathrm{jb} \text { and Ns } \\
\mathrm{y} \text { and sell } \\
\text { nean buy } \\
\text { s are signi }\end{array}$ & $\begin{array}{l}\text { and long } \\
\text { the numbe } \\
\text { nals, respe } \\
\text { mean se } \\
\text { th at the 5c }\end{array}$ & $\begin{array}{l}\text { the short } \\
\text { f buy and } \\
\text { vely. The } \\
\text { from the } \\
\text { evel for a }\end{array}$ \\
\hline Rules & Buy & Sell & Buy-Sell & $\mathbf{S D}_{\mathrm{b}}$ & $\mathbf{S D}_{\mathrm{s}}$ & $\mathbf{N}_{\mathrm{b}}$ & $\mathbf{N}_{\mathrm{s}}$ \\
\hline Full Samp & $-2 / 24 / 200$ & & & & & & \\
\hline$(1,50,0)$ & $\begin{array}{c}0.00069 \\
\left(3.30^{*}\right.\end{array}$ & $\begin{array}{l}-0.00020 \\
-(2.95)^{*}\end{array}$ & $\begin{array}{c}0.00089 \\
(5.2)^{*}\end{array}$ & 0.00737 & 0.01105 & 7042 & 5583 \\
\hline$(1,100,0)$ & $\begin{array}{l}0.00061 \\
(2.67)^{*}\end{array}$ & $\begin{array}{c}-0.00017 \\
(2.59)^{*}\end{array}$ & $\begin{array}{l}0.00078 \\
(4.34)^{*}\end{array}$ & 0.00744 & 0.01125 & 7428 & 5147 \\
\hline$(1,150,0)$ & $\begin{array}{l}0.00053 \\
(2.04)^{*}\end{array}$ & $\begin{array}{l}-0.00010 \\
(-2.14)^{*}\end{array}$ & $\begin{array}{l}0.00064 \\
(3.42)^{*}\end{array}$ & 0.00757 & 0.01137 & 7743 & 4782 \\
\hline$(1,200,0)$ & $\begin{array}{c}0.00048 \\
(1.64)\end{array}$ & $\begin{array}{c}-0.00005 \\
(-1.79)\end{array}$ & $\begin{array}{l}0.00053 \\
(2.81)^{*} \\
\end{array}$ & 0.00766 & 0.01139 & 7863 & 4612 \\
\hline Average & $\begin{array}{l}0.00058 \\
(2.41)^{*} \\
\end{array}$ & $\begin{array}{c}-0.00013 \\
(-2.37)^{*} \\
\end{array}$ & $\begin{array}{l}0.00071 \\
(3.94)^{*}\end{array}$ & 0.00751 & 0.011265 & 7519 & 5031 \\
\hline & & & eriod : 19 & 963 & & & \\
\hline Average & $\begin{array}{c}0.00068 \\
(1.35)\end{array}$ & $\begin{array}{c}-0.00013 \\
(-1.55) \\
\end{array}$ & $\begin{array}{l}0.00081 \\
(2.39)^{*}\end{array}$ & 0.00619 & 0.00886 & 1535.75 & 855.25 \\
\hline & & & eriod : 19 & 973 & & & \\
\hline Average & $\begin{array}{c}0.00042 \\
(1.67) \\
\end{array}$ & $\begin{array}{c}-0.00027 \\
(-1.30) \\
\end{array}$ & $\begin{array}{l}0.00069 \\
(2.41)^{*}\end{array}$ & 0.00472 & 0.00863 & 1383.5 & 1110.5 \\
\hline & & & eriod : 19 & 983 & & & \\
\hline Average & $\begin{array}{c}0.00065 \\
(1.40) \\
\end{array}$ & $\begin{array}{c}-0.00019 \\
(-1.24) \\
\end{array}$ & $\begin{array}{l}0.00084 \\
(2.29)^{*}\end{array}$ & 0.00883 & 0.00970 & 1224.75 & 1303.25 \\
\hline & & & eriod : 19 & 993 & & & \\
\hline Average & $\begin{array}{c}0.00053 \\
(0.41)\end{array}$ & $\begin{array}{c}0.00014 \\
(-0.47)\end{array}$ & $\begin{array}{c}0.00039 \\
(0.68) \\
\end{array}$ & 0.00789 & 0.01475 & 1766.25 & 762.75 \\
\hline & & Sub- & iod : 1994 & $4 / 2004$ & & & \\
\hline Average & $\begin{array}{c}0.24796 \\
(0.64)\end{array}$ & $\begin{array}{c}-0.21509 \\
(-0.22) \\
\end{array}$ & $\begin{array}{c}0.37805 \\
(1.07) \\
\end{array}$ & 0.00683 & 0.01072 & 1282.75 & 857.75 \\
\hline
\end{tabular}

Table III reports the results of Arnold and Rahfeldt moving average trading rules, the ARMA technical trading rules advocated by Arnold and Rahfeldt, (1986, P. 71) are explained as follows: "Buy when the actual price crosses above both moving averages and exit the market when the price crosses below either market moving average". 
The ARMA trading rules compare the price level with two moving averages: moving average short and long. If the price index is above both moving average short and moving average long, the rule emits a buy signal and we will be in the market (buy days); we will be out of the market (sell days) if the price is below either moving average. Therefore the ARMA rules can be summarized as follows:

- $\quad$ If $\mathrm{P}>\mathrm{MA}$ (short) and MA (Long) we will be in the market (buy days)

- $\quad$ If $\mathrm{P} \leq$ either MA (short) or MA (long), we will be out of the market (sell days)

We will consider the ARMA trading rules for short moving average of 5 and 10 days and long moving average of 50,100,150 and 200 days. The results for short moving average of 10 days are not much different than the short moving average of 5 days, therefore not shown.

\section{Table III}

\begin{tabular}{|c|c|c|c|c|c|c|c|}
\hline \multicolumn{8}{|c|}{ Statistical Results for Arnold and Rahfeldt Moving Average Rules } \\
\hline \multicolumn{8}{|c|}{$\begin{array}{l}\text { Results for daily data from } 4 / 1 / 88-2 / 25 / 04 \text {. Rules are identified as (short, long, band) where short and long are the short } \\
\text { and long moving averages and band is percentage difference to generate a signal. } \mathrm{N}_{\mathrm{b}} \text { and } \mathrm{N}_{\mathrm{s}} \text { are the number of buy and } \\
\text { sell signals reported in each period. } \mathrm{SD}_{\mathrm{b}} \text { and } \mathrm{SD}_{\mathrm{s}} \text { are standard deviation of buy and sell signals, respectively. The } \\
\text { numbers in the parentheses are the t-statistics testing the difference of the mean buy and mean sell from the } \\
\text { unconditional 1-day mean, and buy-sell from zero. Numbers marked with asterisks are significant at the } 5 \% \text { level for a } \\
\text { two-tailed test. }\end{array}$} \\
\hline Rules & Buy & Sell & Buy-Sell & $\mathbf{S D}_{\mathrm{b}}$ & $\mathbf{S D}_{\mathrm{s}}$ & $\mathbf{N}_{\mathbf{b}}$ & $\mathbf{N}_{\mathrm{s}}$ \\
\hline \multicolumn{8}{|c|}{ Full Sample: $1 / 2 / 1954-2 / 24 / 2004$} \\
\hline $\mathrm{P}>\mathrm{MA}(5,50)$ & $\begin{array}{l}0.00075 \\
(3.54)^{*}\end{array}$ & $\begin{array}{c}-0.00003 \\
(-2.09)\end{array}$ & $\begin{array}{l}0.00078 \\
(5.00)^{*}\end{array}$ & 0.00720 & 0.01037 & 5246 & 7373 \\
\hline $\mathrm{P}>\mathrm{MA}(5,100)$ & $\begin{array}{c}0.00078 \\
(3.82)^{*}\end{array}$ & $\begin{array}{c}-0.00005 \\
(-2.19)^{*}\end{array}$ & $\begin{array}{c}0.00083 \\
(5.34)\end{array}$ & 0.00711 & 0.01040 & 5146 & 7423 \\
\hline $\mathrm{P}>\mathrm{MA}(5,150)$ & $\begin{array}{c}0.00083 \\
(4.2)^{*}\end{array}$ & $\begin{array}{c}-0.00008 \\
(-2.37)^{*}\end{array}$ & $\begin{array}{c}0.00091 \\
(5.85)^{*}\end{array}$ & 0.00712 & 0.01038 & 5072 & 7446 \\
\hline $\mathrm{P}>\mathrm{MA}(5,200)$ & $\begin{array}{l}0.00081 \\
(4.20)^{*}\end{array}$ & $\begin{array}{c}-0.00007 \\
(-2.28)^{*}\end{array}$ & $\begin{array}{c}0.00088 \\
(5.60)^{*}\end{array}$ & 0.00711 & 0.01041 & 5071 & 7397 \\
\hline Average & $\begin{array}{l}0.00080 \\
(3.90)^{*}\end{array}$ & $\begin{array}{c}-0.00007 \\
(-2.23)^{*}\end{array}$ & $\begin{array}{c}0.00085 \\
(5.45)^{*}\end{array}$ & 0.00714 & 0.01039 & 5133.75 & 7409.75 \\
\hline \multicolumn{8}{|c|}{ Sub-period : $1954-1963$} \\
\hline Average & $\begin{array}{c}0.00113 \\
(3.20)^{*}\end{array}$ & $\begin{array}{c}-0.00021 \\
(-2.23)^{*}\end{array}$ & $\begin{array}{l}0.00134 \\
(4.68)^{*}\end{array}$ & 0.00575 & 0.00825 & 1065.25 & 1321.75 \\
\hline \multicolumn{8}{|c|}{ Sub-period : $1964-1973$} \\
\hline Average & $\begin{array}{c}0.00105 \\
(4.77)^{*}\end{array}$ & $\begin{array}{c}-0.00048 \\
(-2.44)^{*}\end{array}$ & $\begin{array}{c}0.00153 \\
(6.23)^{*}\end{array}$ & 0.00444 & 0.00778 & 950.75 & 1542.25 \\
\hline \multicolumn{8}{|c|}{ Sub-period : 1974-1983 } \\
\hline Average & $\begin{array}{c}0.00088 \\
(1.92)\end{array}$ & $\begin{array}{c}-0.00012 \\
(-1.11)\end{array}$ & $\begin{array}{c}0.00100 \\
(2.65)^{*}\end{array}$ & 0.00867 & 0.00958 & 840.25 & 1686.25 \\
\hline \multicolumn{8}{|c|}{ Sub-period : 1984-1993 } \\
\hline Average & $\begin{array}{c}0.00051 \\
(0.42)\end{array}$ & $\begin{array}{c}0.00033 \\
(-0.36)\end{array}$ & $\begin{array}{c}0.00018 \\
(0.63)\end{array}$ & 0.00769 & 0.01217 & 1149.25 & 1379.75 \\
\hline \multicolumn{8}{|c|}{ Sub-period : 1994-2/24/2004 } \\
\hline Average & $\begin{array}{c}0.02039 \\
(0.41)\end{array}$ & $\begin{array}{c}-0.01235 \\
(-.25)\end{array}$ & $\begin{array}{c}0.03024 \\
(0.57)\end{array}$ & 0.00617 & 0.00988 & 1128.25 & 1479.75 \\
\hline
\end{tabular}

For example the first row of Table III reports results of trading rule of $\mathrm{P}>(5,50)$; we will be in the market (buy days) if the price level is greater than both short moving average of 5 days and long moving average of 50 days and out of the market (sell days) if the price level is less than either moving average. The second row shows the result of AR trading rule for short moving average of 5 days and long moving average of 100 days. We will be in the market 
(buy days) if price is greater than both moving averages of 5 and 100 days and out of the market (sell days) if price is less than either moving average 5 or100 days.

The buy-sell differences (column 4) for the entire period is positive and the t-values for this difference is highly significant, rejecting the null hypothesis of equality with zero. The buy-sell differences for three sub-periods 1954-63, 1964-73, and 1974-83 are positive and statistically significant, rejecting the null hypothesis of equality with zero; however, these buy-sell differences for the sub-periods 1984-93, and 1994-2004 are not significant, implying that we cannot reject the hypothesis that the mean buy days returns is equal to mean sell days returns for these two sub-periods. The mean buy and sell returns are shown in columns 2 and 3 . The full sample t-values for mean buy and mean sell are highly significant, rejecting the null hypothesis that the buy and sell returns equal the unconditional 1day return. For the two sub-periods (1954-63 and 1964-73) the t-values for mean buy or mean sell are statistically significant rejecting the null hypothesis that the buy and sell returns equal the unconditional 1-day return. However, the t-values for mean buy or mean sell for the last three sub-periods are low implying that we cannot reject the null hypothesis that the buy returns equal the unconditional 1-day return in each of the last three sub-periods. The standard deviations of buy days and sell days are reported in Columns 5 and 6 . The standard deviations for buy days are always smaller than those for sell days for the full sample. This implies that the market is less volatile for buy periods than sell periods. Columns 7 and 8 report the number of buys and sells for various rules.

Looking at the full sample, the negative returns in Table II and III for sell days are especially noteworthy. These negative returns cannot be explained by various seasonalities since they are based on 59\% (Table III) and 40\% (Table II) of all trading days. This predictability of returns can reflect either (1) changes in expected returns generated from an equilibrium model, or (2) market inefficiency. Although changes in expected returns are possible, it is hard to imagine an equilibrium model that predicts negative returns over such a large fraction of trading days.

If technical analysis did not have any power to forecast price movements, then we should observe that the buy days returns do not differ appreciably from sell days returns. The results of Table II and III indicate that the average return on buy days is significantly different from the average return on sell days for the full sample and three sub-periods (1954-63, 1964-73, and 1974-84). We conclude that technical trading would work till mid 1980s but since last couple of decades, the S\&P500 has become very efficient and technical trading rules would not work as implied by efficient market hypothesis.

\section{CONCLUSIONS}

Several papers have recently presented evidence that some simple trading rules are useful for predicting stock market returns. In this paper we investigate three moving average trading rules for the S\&P 500 stock index over the period 1954-2004. Overall our results provide mixed results for technical trading rules. Most of the buy-sell differences for earlier period (1954-1984) are positive and the t-values for these differences are highly significant, rejecting the null hypothesis of equality with zero. However for the last two decades the buy-sell differences are not significantly different from zero implying the futility of technical trading rules. We conclude that our results are consistent with market inefficiency from 1954 to 1984 and market efficiency from 1984 to the present.

\section{REFERENCES}

1. Alexander, S. (1964). Price Movements in Speculative Markets: Trends or Random Walks. Industrial Management Review. No. 2, V, 25-46.

2. Arnold, C.M. and Rahfeldt, D. (1986). Timing The Market: How to Profit in Bull and Bear Markets with Technical Analysis. Probus Publishing, Chicago, Illinois.

3. Bessembinder, H. and Chan, K. (1995). The Profitability of Technical Trading Rules in the Asian Stock Markets. Pacific-Basin Finance Journal. 3, 257-284.

4. Bessembinder, H. and Chan, K. (1998). Market Efficiency and Returns to Technical Analysis. Financial Management, 27, (2), 5-17.

5. Brock, W., Lakonishok, J., and LeBaron, B. (1992). Simple Technical Trading Rules and the Stochastic Properties of Stock Returns. Journal of Finance, 47, 1731-64. 
6. Ergul, A., Holmes, P., and Priestley, R. (1997). Technical Analysis, Trading Volume and Market Efficiency: Evidence from an Emerging Market. Applied Financial Economics, 7, 361-365.

7. Fama, E. (1965). The Behavior of Stock Market Prices. Journal of Business, 38, 34-105.

8. Fama, E. (1970). Efficient Capital Markets: A review of theory and empirical work. Journal of Finance, 25:383-417.

9. $\quad$ Fama, E. and Blume, M. (1966). Filter Rules and Stock Market Trading Profits. Journal of Business, 39, 226341.

10. Gencay, R. (1998a). Optimization of Technical trading strategies and profitability in Security Markets. Economics Letter, 59 (2), 249-254.

11. Gencay, R. (1998b). The Predictability of Security Returns with Simple Technical Trading Rules. Journal of Empirical Finance, 5 (4), 347-359.

12. Granger, C. and Morgenstern, O. (1963). Spectral Analysis of New York Stock Market Prices. Kyklos, 16, 127.

13. Jensen, M. and Benington, G. (1970) Random Walks and Technical Theories: Some Additional Evidence, Journal of Finance 25, 469-482.

14. Kwon, K. and Kish, R. (2002). Technical Trading Strategies and Return Predictability: NYSE. Applied Financial Economics, 12, 639-653.

15. Larson, A. (1960). Measurement of Random Process in Futures Prices. Food Research Institute, 1, 313-324.

16. Maillet, B. and Michel, T. (2000). Further Insights on the Puzzle of Technical Analysis Profitability. The European Journal of Finance, 6, 196-224.

17. Mandelbrot, B. (1963). The Variation of Certain Speculative Prices. Journal of Business, 36, 394-419.

18. Osburne, M. (1962). Periodic Structure in the Brownian Motion of Stock Prices. Operations Research, 10, 345-379.

19. $\quad$ Pring, M.J. (1991). Technical Analysis: Explained. McGraw-Hill Co.

20. Pruitt, S. and White, R. (1998). The CRISMA Trading System: Who Says Technical Analysis Can't Beat the Market? Journal of Portfolio Management, 14, (3), 55-58.

21. Ratner, M. and Leal, R.P.C. (1999). Test of Technical Trading Strategies in the Emerging Equity Markets of Latin America and Asia. Journal of Banking and Finance, 23 (1), 1887-1905.

22. Ready, M. (2002). Profits from Technical Trading Rules. Financial Management, autumn 2002, 43-61.

23. Taylor, M. and Allen, H. (1992). The Use of Technical Analysis in the Foreign Exchange market. Journal of International Money and Finance, 11, 304-314.

24. Van Horn, J.C. and Parker, G.C. (1967). The Random Walk Theory: an Empirical Test, Financial Analyst Journal, 23, 87-92. 